\title{
UNIVERSITY OF WISCONSIN RADIOCARBON DATES XIV
}

\author{
MARGARET M BENDER, REID A BRYSON \\ and DAVID A BAERREIS \\ Center for Climatic Research \\ University of Wisconsin, Madison
}

Procedures and equipment of the laboratory have been described in previous date lists. Wood, charcoal, and peat samples are pretreated with dilute $\mathrm{NaOH}$ and dilute $\mathrm{H}_{3} \mathrm{PO}_{4}$ before conversion to the counting gas methane; marls and lake cores are treated with acid only. Very calcareous samples are treated with dilute $\mathrm{HCl}$ instead of $\mathrm{H}_{3} \mathrm{PO}_{4}$.

The dates reported have been calculated using 5568 as the half-life of ${ }^{14} \mathrm{C}$, with 1950 as the reference year. The standard deviation quoted includes only $1 \sigma$ of the counting statistics of background, sample and standard counts. Background methane is prepared from anthracite coal, standard methane from NBS oxalic acid. The activities of the dated samples for which $\delta^{13} \mathrm{C}$ values are listed have been corrected to correspond to a $\delta^{13} \mathrm{C}$ value of $-25 \%$.

\section{ACKNOWLEDGMENTS}

This research is supported by the Office for Climate Dynamics, National and International Programs, National Science Foundation, Grant No. ATM74-23041-A01. We are grateful to the Chemistry Department for the use of the RMS 6-60 mass spectrometer. We also wish to thank Raymond Steventon for technical assistance and Stephen Roth for laboratory assistance.

\section{ARCHAEOLOGIC SAMPLES}

\section{Coffey site (14PO1) series}

\section{A. Kansas}

Charcoal from Coffey site, $\mathrm{N}$ end of Tuttle Creek Reservoir, Pottawatomie Co, Kansas (39 $33^{\prime}$ N, 96 $34^{\prime} \mathrm{W}$ ) excavated 1974 by L J Schmits, Univ Kansas, Lawrence. Site is Archaic with 5 occupation levels separated by sterile alluvium. Subm by D A Baerreis. Radiocarbon dates from previous excavations at site were reported earlier $(\mathrm{R}, 1976$, v 18, p 129-130).

\section{WIS-774. Coffey site (14PO1)}

$$
5080 \pm 65
$$

\section{$3130 \mathrm{BC}$}

Wood charcoal (Ulmus, Populus sp) from Area A, Loc 1, Zone 1, thin stratum of gray-brown silt containing charcoal, burned earth, and cultural debris. Diagnostic artifacts recovered included side-notched and corner-notched projectile points.

WIS-776. Coffey site (14PO1)

$5030 \pm 65$

Charcoal, Feature 28, Area B, Loc 1, Zone 1. 
WIS-778. Coffey site (14PO1)

$\mathbf{5 0 7 0} \pm \mathbf{7 0}$

Charcoal (Celtis sp) and mud from Loc 1, Area B, Zone 2. Zone 2 consisted of reddish brown lens of mottled silt 4 to $5 \mathrm{~cm}$ thick. Artifacts included notched projectile point and base of stemmed projectile point.

\section{WIS-779. Coffey site (14PO1)}

$5140 \pm 65$

Charcoal (Populus sp, Celtis sp) from Loc 1, Area B, Zone 3. Zone 3 consisted of thin occupational level 5 to $10 \mathrm{~cm}$ thick containing basinshaped hearth and 3 circular concentrations of hearthstones.

\section{Mellor site (23CP1) series}

\section{B. Missouri}

Charcoal coll June 1972 from Mellor site at mouth of Lamine R, NW Cooper Co, Missouri $\left(39^{\circ} 00^{\prime} \mathrm{N}, 92^{\circ} 52^{\prime} \mathrm{W}\right.$ ) by Marvin Kay, Illinois State Mus, Springfield, Illinois; subm by D A Baerreis. Previous dates from site were reported earlier (R, 1976, v 18, 130-131).

\section{WIS-771. Mellor site (23CP1)}

$1595 \pm 60$

Charcoal, Cat nos. 203, 212, 215, from Unit B, Trench 9.

\section{WIS-770. Mellor site (23CPI)}

$1555 \pm 60$

Charcoal, Catalog nos. 176, 180, 181, 185, 190, 197, from Unit C, middle portion of upper midden deposits in Trench 9 .

\section{W IS-773. Mellor site (23CP1)}

$1705 \pm 60$ 192.

Charcoal from Unit D, upper midden deposit in Trench 9, Cat no.

\section{W IS-772. Mellor site (23CPI)}

$1730 \pm 60$

Charcoal from Unit $\mathrm{E}$, terminal unit of upper midden deposits in Trench 9, Cat no. 142.

\section{Bontke Shelter site (23MD43) series}

Wood charcoal from Bontke Shelter on Little Sugar Creek drainage, McDonald Co, Missouri (36 $30.47^{\prime}$ N, 94 ${ }^{\circ} 18.29^{\prime}$ W). Coll June 1972 under supervision of $\mathrm{J} \mathrm{E}$ Cobb, Univ Arkansas; subm by D A Baerreis. Site is Late Prehistoric (Freeman, 1959, 1962; Harrington, 1960).

\section{WIS-714. Bontke shelter site (23MD43)}

$525 \pm 60$

Sample 72-625-1027 from Feature 11, Area 3, Sq 2N 4W, 0 to $55 \mathrm{~cm}$ below datum. Assoc with Neosho phase ceramics and lithics. 
WIS-724. Bontke shelter site (23MD43)

Sample 72-625-839 from Area 2, Sq 1.55 10W, 235x35W, 53cm below datum. Assoc with shell-tempered ceramics, triangular arrow points.

WIS-803. Bontke shelter site (23MD43)

$1140 \pm 55$

Sample 72-16-425, charred nutshell and wood, from Area 1, Sq $3 \mathrm{~N}$ $12 \mathrm{~W}$, Feature 1, 20 to $30 \mathrm{~cm}$ below datum.

\section{GEOLOGIC SAMPLES}

\section{Lake Annie site series}

\section{A. Florida}

Lake sediment from Lake Annie, $12.4 \mathrm{~km} \mathrm{~S}$ of Hebring, Highlands Co, Florida $\left(27^{\circ} 12.5^{\prime} \mathrm{N}, 81^{\circ} 21^{\prime} \mathrm{W}\right)$. Coll Feb 1971, by W A Watts, Univ Minnesota; subm by A M Swain, Univ Wisconsin-Madison. Depths indicated are below water surface.

WIS-793. Lake Annie

$$
10,410 \pm 100
$$

Gyttja from 2645 to $2650 \mathrm{~cm}$ depth, top of Ambrosia pollen zone.

WIS-792. Lake Annie

$>\mathbf{2 5 , 0 0 0}$

Gyttja from 2816 to $2821 \mathrm{~cm}$ depth, top of Ceratiola pollen zone.

\section{Sumner Bog series}

$$
\text { B. Iowa }
$$

Peat core for pollen analysis coll July 1974 from Sumner Bog, Bremer Co, Iowa $\left(42^{\circ} 52^{\prime} \mathrm{N}, 96^{\circ} 6^{\prime} \mathrm{W}\right)$ by G R Hallbert, K Van Zant, R G Baker. Subm by G R Hallberg, Iowa Geol Survey, Iowa City, Iowa.

\section{WIS-814. Sumner Bog}

$5520 \pm 70$

Peat from 110 to $116 \mathrm{~cm}$ sec of core.

\section{WIS-811. Sumner Bog} 3570 BC

Peat from 125.5 to $132 \mathrm{~cm} \mathrm{sec}$ of core.

\section{West Okoboji Lake site series}

Core, $1168 \mathrm{~cm}$, coll March 1975 from Little Millers Bay, West Okoboji Lake, Dickinson Co, Iowa $\left(43^{\circ} 22^{\prime} \mathrm{N}, 95^{\circ} 11^{\prime} \mathrm{W}\right)$ by $\mathrm{R} \mathrm{G}$ Baker and K Van Zant, Univ Iowa, Iowa City. Subm by R G Baker. Core ended in till and records late- and postglacial sedimentation within lake (Dodd et al, 1968). Pollen diagram to be constructed from core will be useful in determining climatic changes which affected Cherokee Sewer site. Samples were very calcareous, requiring lengthy acid treatment, which thus added uncertainty to dates. 
WIS-825. West Okoboji Lake site

$390 \pm 55$

Light brown organic lake sediment with snail shell and plant fragments, 60 to $70 \mathrm{~cm}$ sec of core. Increase in Cyperaceae, decrease in $\mathrm{Am}$ brosia, Quercus pollen peaks in abundance in pollen diagrams.

\section{WIS-827. West Okoboji Lake site}

$995 \pm 55$

Light brown organic lake sediment with a few snail shells, 120 to $130 \mathrm{~cm}$ sec. Pollen diagram shows peak in Pinus, increase in Ambrosia, decrease in Gramineae pollen.

WIS-829. West Okoboji Lake site

$2745 \pm 60$

Dark brown silty gyttja, snail shells and plant fragments rare, 250 to $260 \mathrm{~cm}$ depth in core. Increase in Quercus pollen, decrease in Gramineae.

\section{WIS-828. West Okoboji Lake site}

$3240 \pm 65$

Dark brown silty gyttja, a few snail shells and plant fragments, 335 to $345 \mathrm{~cm}$ depth. Increase in Quercus pollen, Ambrosia, Gramineae, and Salix decrease, Tilia reappears in pollen diagram.

WIS-834. West Okoboji Lake site

$5205 \pm 70$

3255 BC

Silty dark brown gyttja, 450 to $460 \mathrm{~cm}$ depth. Sample shows increases in Quercus and other arboreal pollen, increase in Artemisia, decrease in Ambrosia pollen. Typha latifolia pollen peaks in abundance within sample, just before peak in Myriophyllum pollen.

\section{WIS-833. West Okoboji Lake site}

$6210 \pm 70$

Silty gyttja, 578 to $588 \mathrm{~cm}$ depth. Sample overlies $>1 \mathrm{~m}$ sand and gravel and contains Compositeae pollen peak.

WIS-830. West Okoboji Lake site

$7730 \pm 80$ $\mathbf{5 7 8 0 ~ B C}$

Brown gyttja, 740 to $750 \mathrm{~cm}$. Dates beginning of lowest percentages of arboreal pollen. Quercus, Ulmus, and Artemisia pollen percentages decline while Ambrosia increases.

\section{WIS-832. West Okoboji Lake site}

Dark brown organic lake sediment from 930 to $940 \mathrm{~cm}$ sec. Dates rapid decline in Ulmus pollen percentages and rise in Gramineae, $\mathrm{Am}$ brosia and Artemisia abundance.

\section{WIS-836. West Okoboji Lake site}

Black, silty, organic lake sediment from 1040 to $1050 \mathrm{~cm}$ sec. Dates rapid decline in Picea pollen percentages, peak in Betula and Alnus pollen, and rapid increase in Ulnus pollen percentages. 


\section{WIS-835. West Okoboji Lake site}

$12,040 \mathrm{BC}$

Black, silty, organic lake sediment from 1110 to $1120 \mathrm{~cm}$ sec. Dates initial decline in Picea pollen percentages and rise in Fraxinus nigra type and Ambrosia pollen.

\section{Ondris Pond series}

\section{Minnesota}

Lake core coll March 1974 with $5 \mathrm{~cm}$ Livingstone coring device by G L Jacobson, Univ Minnesota, from Ondris Pond, Cass Co, Minnesota $\left(46^{\circ} 21^{\prime} \mathrm{N}, 94^{\circ} 25^{\prime} \mathrm{W}\right)$. Subm by A M Swain.

\section{WIS-799. Ondris Pond}

$$
660 \pm 55
$$

Detrital gyttja, 205 to $215 \mathrm{~cm}$ segment of core, water depth $180 \mathrm{~cm}$. Segment contained beginning of Late Holocene increase in Ambrosia pollen and large fragments of macrophytes as well as algal detritus. Sample dated to check for possible error in age caused by carbonates in till of region.

\section{WIS-798. Ondris Pond}

$$
1535 \pm 60
$$

AD 415

Detrital gyttja, 260 to $268 \mathrm{~cm}$ of core, segment contained beginning of Late Holocene increase in Pinus pollen. Dates migration of Pinus sp (primarily diploxylon) into area of calcareous outwash following midpostglacial expansion of prairie in region.

\section{Nelson Pond series}

Lake sediment core coll Dec 1974 by G L Jacobson, E J Cushing, $\mathrm{H}$ E Wright, Univ Minnesota, from Nelson Pond, Pine Co, Minnesota $\left(46^{\circ} 24^{\prime} \mathrm{N}, 92^{\circ} 41^{\prime} \mathrm{W}\right)$. Subm by A M Swain. Segments dated bracket Holocene increase in Pinus strobus pollen used to estimate sedimentation rate in basin during portion of Holocene (Wright \& Watts, 1969).

\section{WIS-797. Nelson Pond}

$5540 \pm 70$ 3590 вс

Algal gyttja, 1158 to $1168 \mathrm{~cm}$ sec, occasionally banded and possibly varved. Segment $60 \mathrm{~cm}$ above beginning of Holocene increase in Pinus strobus pollen.

WIS-795. Nelson Pond

$7245 \pm 75$ 5295 вс

Algal gyttja, 1278 to $1288 \mathrm{~cm}$ sec, $60 \mathrm{~cm}$ below beginning of Pinus strobus pollen.

\section{Billy's Lake series}

Lake sediment core coll March 1974 by G L Jacobson, E J Cushing, H E Wright from Billy's Lake, Morrison Co, Minnesota $\left(46^{\circ} 16^{\prime} \mathrm{N}, 94^{\circ}\right.$ $33^{\prime}$ W). Samples dated as part of study of migration of several forest species in Minnesota (McAndrews, 1966). Subm by A M Swain. 
WIS-806. Billy's Lake

$990 \pm 55$

Detrital gyttja, 220 to $230 \mathrm{~cm}$ sec of core. Water depth at site was $180 \mathrm{~cm}$. Segment was below beginning of Late Holocene increase in $\mathrm{Am}$ brosia pollen. Sample dated to check for possible error in age caused by carbonates in outwash of region.

\section{WIS-804. Billy's Lake}

$2000 \pm 55$

Detrital gyttja, 295 to $305 \mathrm{~cm}$ sec of core. Segment contained beginning of Late Holocene increase in Pinus pollen. Dates migration of Pinus species (haploxylon and diploxylon) into area of calcareous till.

\section{Willow River Pond series}

Lake core coll March 1972 by G L Jacobson from Willow River Pond, Pine Co, Minnesota $\left(46^{\circ} 18^{\prime}\right.$ N, $92^{\circ} 47^{\prime}$ W). Segments dated bracket Holocene increase in Pinus strobus pollen used to estimate sedimentation rate in this basin during portion of Holocene (Wright \& Watts, 1969). Subm by A M Swain.

\section{WIS-800. Willow River Pond}

$5160 \pm 65$

Algal gyttja from 860 to $870 \mathrm{~cm}$ of core.

\section{WIS-802. Willow River Pond}

3210 BC

Algal gyttja from 980 to $990 \mathrm{~cm}$ of core.

\section{Longswamp site series}

\section{Pennsylvania}

Sediment cores coll 1973 by W A Watts from lake $1 \mathrm{~km}$ SW of Longswamp and $1.6 \mathrm{~km} \mathrm{~S}$ of Mertztown, Berks Co, Pennsylvania $\left(40^{\circ} 29^{\prime} \mathrm{N}\right.$, $75^{\circ} 40^{\prime} \mathrm{W}$ ). Samples dated to show chronology of vegetational changes in area and, in particular, migration periods of dominant trees (Watts, 1975). Depths indicated were below mud surface. Subm by A M Swain.

WIS-783. Longswamp site

$9705 \pm 100$

Organic silt from 70 to $77 \mathrm{~cm}$ depth, end of fir-jackpine pollen zone.

\section{WIS-782. Longswamp site}

$12,060 \pm 120$

Organic silt from 150 to $155 \mathrm{~cm}$ depth, base of fir-jackpine pollen zone.

\section{0,110 в}

WIS-780. Longswamp site

$12,540 \pm 120$

Organic silt from 230 to $235 \mathrm{~cm}$ depth, base of spruce pollen $z$. 
WIS-805. Longswamp site

$12,200 \pm 110$

Gray silt from base of dwarf birch zone. Material from 2 cores used for dating.

\section{WIS-807. Longswamp site}

Gray silt from 375 to $395 \mathrm{~cm}$ depth, tundra zone.

\section{0,145 BC}

\section{Criders Pond series}

Lake sediment core coll 1971 by W A Watts from Criders Pond, N of Phillamon Run, $3.2 \mathrm{~km}$ E of Scotland, Franklin Co, Pennsylvania (39 ${ }^{\circ}$ $\left.57.5 \mathrm{~N}, 77^{\circ} 32.6^{\prime} \mathrm{W}\right)$. Depths indicated are below water surface. Subm by A M Swain.

WIS-788. Criders Pond

$$
11,650 \pm 130
$$

9700 BC

Clayey detritus gyttja from 135 to $140 \mathrm{~cm}$ depth, white pine pollen maximum.

\section{WIS-787. Criders Pond}

Clayey silt from 400 to $410 \mathrm{~cm}$ depth, end of spruce pollen zone.

\section{Tannersville site series}

Lake sediment core coll 1973 by W A Watts from Cranberry Bog Preserve, $3 \mathrm{~km}$ E of Lower Tannersville, Monroe Co, Pennsylvania ( $41^{\circ} 02^{\prime}$ $\left.\mathrm{N}, 75^{\circ} 16^{\prime} \mathrm{W}\right)$. Depths indicated were below peat surface. Subm by A M Swain.

\section{WIS-790. Tannersville site}

$4610 \pm 70$

Gyttja from 525 to $530 \mathrm{~cm}$ depth, pollen zone shows hemlock decrease.

WIS-784. Tannersville site

$8390 \pm 85$

Gyttja from 810 to $815 \mathrm{~cm}$ depth, rise of beech pollen found in palynol study of core.

WIS-789. Tannersville site

$9835 \pm 95$

7885 BC

Gyttja from 1040 to $1045 \mathrm{~cm}$ depth, rise of hemlock in pollen zone.

WIS-791. Tannersville site

$10,860 \pm 100$

Gyttja from 1140 to $1145 \mathrm{~cm}$ depth, rise of white pine zone in pollen.

$13,330 \pm 120$

WIS-781. Tannersville site

11,380 BC

Silty gyttja from 1240 to $1245 \mathrm{~cm}$ depth, end of sedge zone in pollen. 


\section{Granberry Glades Botanical Area series}

\section{E. West Virginia}

Core coll 1971 from Cranberry Glades Botanical Area, Monongahela Natl Forest, Pocahontas Co, $24 \mathrm{~km} \mathrm{E}$ of Richwood, West Virginia $\left(38^{\circ}\right.$ $10^{\prime} \mathrm{N}, 80^{\circ} 15^{\prime} \mathrm{W}$ ) by W A Watts. Subm by A M Swain.

\section{WIS-794. Cranberry Glades}

$4900 \pm 65$

Peat 251 to $256 \mathrm{~cm}$ below bog surface, pollen diagram shows decrease in hemlock.

WIS-785. Cranberry Glades

$12,185 \pm 110$

Organic clay from 360 to $365 \mathrm{~cm}$ below bog surface. Decrease of spruce-pine in pollen diagram.

\section{White Clay Lake series}

\section{F. Wisconsin}

Core coll Feb 1974 from White Clay Lake, Shawano Co, Wisconsin $\left(45^{\circ} 48^{\prime} \mathrm{N}, 88^{\circ} 25^{\prime} \mathrm{W}\right)$ by James Peterson, Univ Wisconsin-Madison. Subm by A M Swain. Palynol study of core is in progress.

\section{WIS-812. White Clay Lake}

$780 \pm 50$ in pollen.

Light brown gyttja; 50 to $55 \mathrm{~cm} \mathrm{sec} \mathrm{of} \mathrm{core,} \mathrm{at} \mathrm{base} \mathrm{of} \mathrm{Ambrosia} \mathrm{rise}$

\section{WIS-775. White Clay Lake}

$1260 \pm 60$

Dark-brown gyttja, 120 to $138 \mathrm{~cm}$ sec of core.

\section{Kickapoo River System series}

Upper Kickapoo River Valley was selected for continuing study of paleohydrol episodes of Driftless Area of SW Wisconsin (Knox, 1972; Knox \& Johnson, 1974). Previous dates in this study were reported earlier (R, 1975, v 17, p 132-133; R, 1976, v 18, p 134-137). All samples id by R Miller, Forest Products Lab, Madison. Samples coll 1975 by W C Johnson and P W Dunwiddie; subm by W C Johnson and J C Knox, Univ Wisconsin-Madison. Sites included are Kickapoo R, Brush Creek, Upper Brush Creek, Morris Creek, and Spring Valley Creek.

\section{WIS-801. Kickapoo River site}

$5675 \pm 70$

Quercus sp, $280 \mathrm{~cm}$ deep, buried at gravel-fine sediment contact at base of left stream bank of Kickapoo R, Monroe Co, Wisconsin $\left(43^{\circ} 50^{\prime}\right.$ $\left.\mathrm{N}, 90^{\circ} 30^{\prime} \mathrm{W}\right)$.

\section{WIS-810. Upper Brush Creek}

$$
\begin{gathered}
\mathbf{4 3 8 0} \pm 65 \\
\mathbf{2 4 3 0} \text { BC } \\
\delta^{13} C=-28.9 \% 0
\end{gathered}
$$

Wood $210 \mathrm{~cm}$ from top of bank stream exposure of Upper Brush Creek, Monroe Co, Wisconsin $\left(43^{\circ} 44^{\prime} \mathrm{N}, 90^{\circ} 41^{\prime} \mathrm{W}\right)$. 


\section{WIS-813. Upper Brush Creek}

$5045 \pm 70$

3095 BC

$\delta^{13} C=-28.5 \%$

Wood from $\log$ in sandy unit ca $225 \mathrm{~cm}$ from top of exposure, right stream bank, Monroe Co, Wisconsin ( $43^{\circ} 44^{\prime} \mathrm{N}, 90^{\circ} 42^{\prime} \mathrm{W}$ ).

\section{WIS-808. Brush Creek}

$2065 \pm 55$

$1150 \mathrm{BC}$

$\delta^{13} C=-26.2 \%$ o

Prunus sp, $\log 305 \mathrm{~cm}$ deep in sandy unit overlying gravel in right bank of Brush Creek, Vernon Co, Wisconsin (43 $\left.44^{\prime} \mathrm{N}, 90^{\circ} 36^{\prime} \mathrm{W}\right)$.

\section{WIS-837. Morris Creek}

$3125 \pm 65$

1175 BC

$\delta^{13} C=-27.5 \%$

Outer 10 rings of log, Quercus sp, $26 \mathrm{~cm}$ diam, partially buried at left bank of stream cut exposure of Morris Creek, Monroe Co, Wisconsin $\left(43^{\circ} 46^{\prime} \mathrm{N}, 90^{\circ} 35^{\prime} \mathrm{W}\right)$.

\section{WIS-831. Spring Valley Creek}

$1225 \pm 60$ AD 725

$\delta^{13} C=-27.6 \%$

Outer 5 rings of $\log$, Quercus $\mathrm{sp}, 33 \mathrm{~cm}$ diam excavated from base of left bank stream exposure on basal gravel unit of Spring Valley Creek, Monroe Co, Wisconsin $\left(43^{\circ} 48^{\prime} \mathrm{N}, 90^{\circ} 36^{\prime} \mathrm{W}\right)$.

\section{WIS-809. Hub City Bog site}

$6865 \pm 175$

$4915 \mathrm{BC}$

Decomposed peat with Larix macrofossils, id by $\mathrm{R}$ Miller, Forest Prods Lab, Madison, Wisconsin) from 145 to $150 \mathrm{~cm}$ level of $3 \mathrm{~m}$ core containing $2.6 \mathrm{~m}$ peat over silt that grades downward into sand. Sample dates peat regeneration above trash layer of Larix macrofossils assumed to represent hiatus. Other dates from Hub City Bog were reported earlier (R, 1976, v 18, p 137). Coll Nov 1974 by A M Davis, Boston Univ, Boston, Massachusetts, from Hub City Bog, Richland Co, Wisconsin $\left(43^{\circ} 28^{\prime} \mathrm{N}\right.$, $\left.90^{\circ} 21^{\prime} \mathrm{W}\right)$. Subm by A M Davis.

\section{WIS-786. Stiles site}

$9335 \pm 90$

\section{5 вC}

Bones of nearly complete skeleton of Elephas primigenius from 1.73 to $2.01 \mathrm{~m}$ below surface, in clay deposit which seems to represent old lake near Lake Mills, Jefferson Co, Wisconsin $\left(43^{\circ} 6^{\prime} \mathrm{N}, 88^{\circ} 46^{\prime} \mathrm{W}\right)$. Excavated 1974 and subm by J E Dallman, Univ Wisconsin-Madison.

$$
\text { G. Wyoming }
$$


subm by R G Baker. Pollen analysis of core is underway. Depths are below floating mat surface.

\section{WIS-816. Floating Island Lake}

$3070 \pm 65$

Sample FIL-A-IV, brown fibrous peat from 380 to $390 \mathrm{~cm}$ sec of $10 \mathrm{~m}$ core. Sample overlay zone of relatively frequent aquatic pollen and underlay increase in Cyperaceae, Gramineae and Chenopodiaceae-Amaranthaceae pollen. Event suggests change in hydrol regime for Lake.

\section{WIS-817. Floating Island Lake}

$7400 \pm 85$

Sample FIL-A-III, fibrous peat with wood fragments from 815 to $825 \mathrm{~cm}$ sec of $10 \mathrm{~m}$ core. Pollen zone contained small, postglacial spruce peat.

\section{WIS-819. Floating Island Lake}

$9090 \pm 90$

Sample FIL-A-II, fine-grained brown peat and very organic silty, gray-brown clay from 945 to $955 \mathrm{~cm}$ depth of $10 \mathrm{~m}$ core. Interval at which arboreal pollen changed from maximum spruce, low pine, to low spruce, high pine.

\section{WIS-822. Floating Island Lake}

$9225 \pm 90$

Sample FIL-A-I, gray organic silt, from 982 to $992 \mathrm{~cm}$ depth of $10 \mathrm{~m}$ core.

\section{WIS-824. Floating Island Lake}

$10,115 \pm 95$ 8165 BC

Sample FIL-B-I, organic micaceous silt from 1073 to $1088 \mathrm{~cm}$ depth of $11.5 \mathrm{~m}$ core. Sediment represents initial deposition following retreat of Pinedale Glacier.

\section{WIS-820. Beaver Lake, Bighorn Mts}

$9890 \pm 95$ 7940 BC

Basal organic sediment from Beaver Lake (informal name), $2560 \mathrm{~m}$ alt in Bighorn Co, Wyoming (44 $\left.14^{\circ} \mathrm{N}, 107^{\circ} 15^{\prime} \mathrm{W}\right)$. Coll June 1974 by R G Baker, M R Burkart; subm by R G Baker. Sample BL-B-I, 147 to $157 \mathrm{~cm}$ sec of $5.1 \mathrm{~cm}$ diam core. Depth indicated is below lake bottom.

$H$. Northwest Territories

WIS-777. Grant Lake site

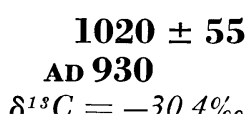




\section{WIS-823. Nicol Lake site, NWT}

Basal $3 \mathrm{~cm}$ of $41 \mathrm{~cm}$ peat monolith overlying permafrost cobbles. Coll July 1975 by P A Kay from SW end of Nicol Lake, Mackenzie Dist, NWT, Canada $\left(61^{\circ} 35^{\prime} \mathrm{N}, 103^{\circ} 29^{\prime} \mathrm{W}\right)$. Pollen of peat monolith is being analyzed.

\section{WIS-826. Slow River site, NWT}

Basal $3 \mathrm{~cm}$ of $39 \mathrm{~cm}$ peat monolith overlying permafrost cobbles. Coll July 1975 by P A Kay from sedge meadow, $1 \mathrm{~km} \mathrm{~S}$ of Slow R, $5 \mathrm{~km} \mathrm{E} \mathrm{of}$ Dubawnt Lake, Keewatin Dist, NWT (63 $\left.02^{\prime} \mathrm{N}, 100^{\circ} 45^{\prime} \mathrm{W}\right)$.

\section{REFERENCES}

Bender, M M, Bryson, $\mathrm{R}$ A, and Baerreis, D A, 1975, University of Wisconsin radio. carbon dates XII: Radiocarbon, v 17, p 121-134.

1976, University of Wisconsin radiocarbon dates XIII: Radiocarbon, v 18, p $125-139$.

Dodd, I D, et al, 1968, A consideration of pollen diatoms and other remains in postglacial sediments: Iowa Acad Sci Proc, v 75, p 197-209.

Freeman, J E, 1959, The Neosho focus, a late prehistoric culture in Northeastern Oklahoma: PhD dissert, Univ Wisconsin.

1962, The Neosho focus, a later prehistoric culture in Northeastern Okla homa: Oklahoma Anthropol Soc Bull, v 10, p 1-25.

Harrington, M R, 1960, The Ozark Bluff Dwellers: Indian notes and mons, v 12, Mus Am Indian, Heye Foundation, New York.

Knox, J C, 1972, Valley alluviation in southwestern Wisconsin: Annals Assoc Am Geog, v 62, no. 3 , p 401-410.

Knox, J C and Johnson, W C, 1974, Late Quaternary valley alluviation in the Driftless Area of southwestern Wisconsin in: Knox, J C and Mickelson, D M (eds), Late Quaternary environments of Wisconsin, Am Quaternary Assoc, 3rd biennial mtg, Madison, July 28-Aug 2, p 134-162.

McAndrews, J H, 1966, Postglacial history of prairie, savanna, and forest in northwestern Minnesota: Torrey Bot Club Mem, v 22, 72 p.

Ruhe, R V, Dietz, W P, and Fenton, T E, 1968, Iowan drift problem, northeastern Iowa: Iowa Geol Survey Rept Invest no. 7, 40 p.

Sorenson, C J, Knox, J C, Larsen, J A, and Bryson, R A, 1971, Paleosols and the forest border in Keewatin, NWT: Quaternary Research, v 1, no. 4, p. 468-473.

Watts, W A, 1975, Quaternary vegetational history of the southeastern United States, in: Appalachian Geobot: Univ Tennessee Press (in press).

Wright, H E and Watts, W A, 1969, Glacial and vegetational history of northeastern Minnesota: Minnesota Geol Survey Spec Pub SP-11, 59 p. 